\title{
Nilai Pendidikan Antikorupsi dalam Puisi Karya Ahmad Mustofa Bisri
}

\author{
Chafit Ulya ${ }^{\mathrm{a}, 1}$, Nugraheni Eko Wardani ${ }^{\mathrm{a}, 2}$
}

${ }^{a}$ Universitas Sebelas Maret, Surakarta, Indonesia

${ }^{1}$ chafit@staff.uns.ac.id; ${ }^{2}$ buheniwardani@gmail.com

\begin{tabular}{ll}
\hline Article info & ABSTRACT \\
\hline Article history: & This research aims at describing and explaining: (1) anti-corruption \\
Received: 12-10-2019 & values in A. Mustofa Bisri's poetry; (2) the relevance of the anti- \\
Accepted: 24-02-2020 & corruption values in A. Mustofa Bisri's poetry as an anti-corruption \\
& literacy material in poetry appreciation lesson at high school level. \\
& This research applies descriptive qualitative method by collecting the \\
& data from a poetry collection 'Aku Manusia'. There are 47 poetries in \\
& that book which nine of them are then chosen under thematic and \\
& semantic considerations. Based on the data analysis, it shows that (1) \\
& there are nine anti-corruption values implied in the poetries, those are \\
& honesty, true to self, responsibility, injustice, contemplation, sincerity, \\
& modesty, wealth, and self-control. (2) Those values in A. Mustofa \\
& Bisri's poetry can be used as a learning material in enriching anti- \\
& corruption literacy in poetry appreciation lesson.
\end{tabular}

Keywords: anti-corruption values anti-corruption poetry A. Mustofa Bisri
Penelitian ini bertujuan mendeskripsikan dan menjelaskan: (1) nilainilai pendidikan antikorupsi yang terdapat dalam puisi karya A. Mustofa Bisri; (2) relevansi nilai antikorupsi dalam puisi karya A. Mustofa Bisri dalam pembelajaran apresiasi puisi di SMA. Penelitian ini menggunakan metode deskriptif kualitatif dengan sumber data berupa kumpulan puisi $A k u$ Manusia. Ada 47 puisi dalam buku tersebut yang selanjutnya dipilih sembilan puisi dengan pertimbangan tematik dan makna yang dikandung. Berdasarkan hasil analisis yang sudah dilakukan, dapat ditarik simpulan bahwa (1) ada tujuh nilai pendidikan antikorupsi yang dapat dipetik dari puisi A. Mustofa Bisri, yaitu kejujuran, kemandirian, tanggung jawab, keadilan, keikhlasan, kesederhanaan, dan pengendalian diri. (2) Nilai-nilai antikorupsi dalam puisi A. Mustofa Bisri dapat dijadikan sebagai materi untuk memperkaya literasi antikorupsi dalam pembelajaran apresiasi puisi.

Copyright () 2020 Institut Agama Islam Negeri Syekh Nurjati Cirebon.

\section{PENDAHULUAN}

A. Mustofa Bisri merupakan satu di antara sedikit penyair besar Indonesia yang memiliki latar belakang sebagai seorang ulama. Dalam tradisi Islam di Timur Tengah, ada nama Jalaludin ar-Rumi yang menyandingkan jalur kepenyairan dengan keulamaan dan di Indonesia ada A. Mustofa Bisri. Reputasi A. Mustofa Bisri sebagai penyair sama besarnya dengan perannya sebagai ulama. Kedua peran tersebut bahkan selalu dijalankan berdampingan secara harmonis. Kombinasi tersebut diulas oleh Alniezar (2018) dalam tulisannya yang bertajuk "Gus Mus: Kiai yang Penyair, Ulama yang Pemikir". Latar belakang ulama inilah yang menjadikan puisi A. Mustofa Bisri tidak sekadar bernilai keindahan, tetapi juga kaya akan nilai-nilai luhur kehidupan.

Secara teoretis, puisi memang memiliki dua dimensi yang tidak bisa dilepaskan. Pertama, sebuah puisi diciptakan untuk kebutuhan keindahan karena puisi dapat memberikan kesan kesenangan atau hiburan kepada pembaca (Perrine, 1974). 
Kedua, puisi lahir dari kata hati, suara nurani yang di dalamnya ada cahaya Ilahi, yang bertujuan untuk mentransformasi dan menanamkan nilai-nilai kehidupan (Mahayana, 2016). Karya puisi A. Mustofa Bisri merupakan kombinasi harmonis dari kedua dimensi tersebut.

Selain dikenal sebagai ulama besar, A. Mustofa Bisri juga seorang penyair dengan karya-karya puisi yang tidak kalah besarnya. Latar belakang ulama inilah yang menyebabkan karya-karya puisinya sarat dengan muatan nilai-nilai kehidupan. Nilai tersebut tidak saja berkaitan dengan aspek religiusitas, tetapi juga nilai kemanusiaan secara luas. Berkaitan dengan aspek religiusitas, sudah banyak kajian yang membahas karya-karya A. Mustofa Bisri dengan perspektif tersebut. Beberapa di antaranya adalah kajian yang dilakukan oleh Dhanu Widi Wijaya menyimpulkan bahwa puisi-puisi Mustofa Bisri merepresentasikan keindahan dan cinta Ilahiah dalam posisinya sebagai "kekasih" Tuhan (Wijaya, 2018).

Selain dalam bentuk puisi, A. Mustofa Bisri juga banyak menulis cerpen. Sama halnya dengan puisi, latar belakang keagamaan lagi-lagi menjadi pijakan dalam karyakarya cerpen yang dihasilkan. Ada dua kajian yang setidaknya menunjukkan dominasi nilai religius dalam karya cerpen A. Mustofa Bisri. Pertama, kajian yang dilakukan oleh Tiara Melfaliona Shandy. Ada tiga dimensi nilai religius dalam karya cerpen Gus Jakfar, yaitu nilai religius dalam hubungannya manusia dengan Tuhan, nilai religius antarsesama manusia, dan nilai religius antara manusia dengan dirinya sendiri (Shandy, 2016). Kedua, kajian yang dilakukan oleh Nakti, Gazhali, dan Maryaeni. Terdapat norma mutlak dari Tuhan dalam kumpulan cerpen Lukisan Kaligrafi terbagi menjadi tiga, yaitu (a) taubatan nasuha, yaitu tobat yang dilakukan atas kesadaran hati terdalam disertai tekad tidak mengulangi perbuatan dosa, (b) wara', yaitu menjauhi atau meninggalkan segala hal yang belum jelas haram dan halalnya, dan (c) ridha atau rida, yaitu menerima apa saja yang telah ditetapkan Tuhan, baik yang menyusahkan maupun menyenangkan (Nakti, Gazhali, \& Maryaeni, 2016).

Selain berkaitan dengan aspek religiusitas, karya-karya A. Mustofa Bisri juga banyak dikaji dengan berbagai sudut pandang, salah satunya adalah nilai kemanusiaan. Hal ini terdapat pada penelitian Nurlina Arisnawati yang menyimpulkan bahwa kemiskinan dalam puisi-puisi A. Mustofa Bisri digambarkan melalui pembangunan tidak merata yang hanya bisa dirasakan oleh orang kaya, profesi atau pekerjaan dengan upah rendah, ketidakadilan di bidang hukum, bahkan kemiskinan hanya dijadikan objek permainan di kalangan elite dan orang-orang kaya (Arisnawati, 2011). Latar belakang sosial-politik banyak dijadikan sumber ide penciptaan karya oleh A. Mustofa Bisri sehingga karya-karyanya lekat akan nilai-nilai kemanusiaan. Sebut saja puisi "Permainan Golf' yang memetaforakan hubungan antara penguasa dengan rakyat kecil seperti permainan golf. Bola kecil terhempas tinggi melambung / untuk kemudian terbanting limbung / tangan dan tongkat perkasa kembali bergabung / menggenjotnya jatuh jauh ke ujung (Bisri, 2005).

Mustofa Bisri memang tidak segan-segan melontarkan kritik-kritik keras terhadap pemerintah akibat praktik ketidakadilan yang akhirnya menimbulkan persoalan di kalangan masyarakat bawah. Posisinya sebagai seorang kiai/ulama, pengasuh pondok pesantren, sekaligus tokoh masyarakat itulah yang membuatnya merasa bertanggung jawab terhadap masalah sosial kemasyarakatan (Mujiningsih, 2007). Meskipun sering mengkritisi pemerintah melalui karya-karyanya, A. Mustofa Bisri tidak tercatat sebagai seorang sastrawan yang dianggap berbahaya bagi pemerintah, khususnya pemerintah Orde Baru. Berbeda dengan Rendra, Taufik Ismail, 
atau Emha Ainun Nadjib yang sering mendapatkan pencekalan karena karyanya dianggap terlalu berani.

Dua alasan A. Mustofa Bisri tidak dianggap berbahaya. Pertama, latar belakangnya sebagai seorang kiai/ulama, pengasuh pondok pesantren, sekaligus tokoh masyarakat. Sebagai tokoh masyarakat yang terpandang, A. Mustofa Bisri dituntut atau memang sudah menjadi karakternya, memiliki citra diri yang positif meskipun berada pada posisi berseberangan dengan pihak penguasa. Dalam puisi "Kau Ini Bagaimana atau Aku Harus Bagaimana" terlihat meskipun A. Mustofa Bisri dalam posisi mengkritisi pemerintah tetap mampu menampilkan sosok yang santun, toleran, mau diatur, dan bertanggung jawab untuk menghindari konflik dengan pemerintah (Wahyuni, 2016).

Kedua, puisi atau karya sastra bagi A. Mustofa Bisri merupakan jalan dakwah untuk amar ma'ruf nahi munkar (Mujiningsih, 2007). Jadi, meskipun bernada protes, karya-karya A. Mustofa Bisri lebih banyak dinilai sebagai bagian dari ilmu agama yang memberikan pencerahan bagi umat manusia dengan berbagai persoalan hidupnya. Selain itu, karya-karya A. Mustofa Bisri lekat dengan tradisi sufi yang bertemakan cinta dan kerinduan kepada Allah (Wachid, 2015). Kalau pun muncul protes di dalam karyanya, hal itu merupakan bagian dari perwujudan cinta dan kerinduan kepada Allah. Bahkan dalam tulisannya yang lain, Wachid pun menguatkan bahwa kepenyairan A. Mustofa Bisri berangkat dari Al Qur’an dan Alhadis. A. Mustofa Bisri menulis setiap karya dengan melandaskan pada nilai-nilai spiritualitas, mentransfer kebijaksanaan atau hikmah, serta menemukan kemuliaan hidup (Wachid, 2008).

Berdasarkan hal tersebut dapat ditarik simpulan bahwa aspek religiuslah yang banyak mendominasi makna dan suasana dalam karya puisi A. Mustofa Bisri. Pemahaman dan penerapan yang mendalam terhadap nilai-nilai keagamaan tersebut kemudian melahirkan karya-karya yang sarat dengan nilai-nilai luhur kehidupan, tidak terkecuali nilai antikorupsi. Dalam situasi bangsa yang masih berjuang melawan korupsi, penggalian nilai-nilai antikorupsi dalam puisi memiliki posisi penting bagi upaya penanaman nilai antikorupsi. Puisi memiliki peranan penting dalam upaya menanamkan nilai-nilai, membangun kesadaran estetik melalui permainan bahasa figuratif (Mahayana, 2016). Melalui simbolisme, metafora, asosiasi, atau paradoks, puisi dapat dijadikan menara pikiran dalam membentuk citra dan stigma. Tidak terkecuali penanaman nilai antikorupsi melalui pembangunan citra dan stigma negatif pada korupsi dan pelakunya.

Puisi memiliki hubungan erat dengan masalah korupsi. Hubungan paling nyata ditunjukkan oleh Gerakan Puisi Menolak Korupsi (PMK) yang dikomandoi oleh Sosiawan Leak. Gerakan PMK ini secara aktif sejak 2013 turut serta mengampanyekan upaya penolakan dan perlawanan terhadap korupsi melalui jalan puisi (Ulya, Wardani, \& Mujiyanto, 2016). Dari gerakan ini, telah dihasilkan ribuan puisi yang secara khusus membidik masalah korupsi dengan berbagai sudut pandang penulisnya. Sudah sejak lama puisi dijadikan senjata untuk melawan berbagai praktik kenegaraan yang tidak adil, tidak transparan, otoriter, dan sebagainya. Beberapa kajian tentang hubungan puisi dengan sistem sosial politik suatu negara ditunjukkan melalui penelitian Anedo (2011) yang menemukan bahwa puisi dapat dijadikan senjata ampuh untuk menyatukan bangsa. Bahkan, puisi-puisi bernada protes dapat pula mengubah sistem politik suatu negara (Srestha, 2000).

Di Indonesia, ada W.S. Rendra dan Widji Thukul yang banyak menulis puisi yang mengangkat keberpihakan terhadap kaum yang tertindas dan dimarjinalkan (Tjahjono, 2012). Keberadaan Rendra dan Widji bahkan sampai 
dianggap sebagai ancaman bagi pemerintah Indonesia pada waktu itu sehingga perlu dicekal bahkan sampai diculik dan dihilangkan. "Mereka justru hanya memiliki senjata, kita punya kata", begitulah yang dikatakan Rendra dalam Horison (Rendra, 1982).

Berdasarkan hal tersebut dapat dinyatakan bahwa puisi memiliki peran penting yang tidak dapat dikesampingkan dalam hubungannya dengan persoalan korupsi di Indonesia. Melalui puisi, penyair dapat mengekspresikan gagasan, ide, pemikiran, ataupun perasaan berkaitan dengan persoalan yang memprihatinkan tersebut. Melalui puisi, penyair juga menitipkan pesan-pesan moral, baik dalam kaitannya secara langsung dengan nilai antikorupsi maupun nilai-nilai dasar secara umum, yang dapat diserap dan dihayati oleh pembaca.

Berangkat dari pemikiran inilah, penelitian ini dilakukan sebagai upaya untuk mengangkat nilai-nilai antikorupsi yang terdapat dalam puisi-puisi A. Mustofa Bisri. Nilai-nilai antikorupsi tersebut akan mampu menjadi bahan untuk memperkaya literasi antikorupsi bagi generasi muda, utamanya siswa SMA. Berdasarkan latar bekalang tersebut, penelitian ini bertujuan untuk mendeskripsikan dan menjelaskan: (1) nilai-nilai antikorupsi yang terdapat dalam puisi karya A. Mustofa Bisri; dan (2) relevansi nilai antikorupsi dalam puisi karya A. Mustofa Bisri sebagai bahan literasi antikorupsi dalam pembelajaran apresiasi puisi di SMA.

\section{METODE}

Penelitian ini menggunakan metode deskriptif kualitatif dengan teknik analisis data kualitatif yang bersifat induktif, yaitu bahwa kajian ini dilakukan tidak dalam rangka membuktikan hipotesis, tetapi menarik simpulan berdasarkan hasil analisis data yang dilakukan dengan berpegangan pada teori yang ada (Sutopo, 2006). Sumber data penelitian diambil dari buku kumpulan puisi Aku Manusia karya A. Mustofa Bisri yang diterbitkan pada tahun 2016. Ada 47 puisi yang menjadi populasi dalam kajian ini. Dari 47 puisi yang ada, dipilih 9 puisi secara purposive sampling. Sembilan puisi tersebut dipilih berdasarkan kecenderungan tematik yang diangkat dengan mengedepankan nilai antikorupsi yang ada dalam puisi. Kesembilan puisi tersebut adalah "Misteri", "OrangOrang Negeriku", "Banyak yang Tinggal", "Tahakkumi", "Berapa Lama", "Bagaimana Aku Menirumu, O Kekasih", "Kurban”, "Kepada Anakku”, dan "Tentang Dua Orang Kaya dan Miskin". Puisi-puisi tersebut dianalisis secara interpretatif dengan melandaskan pada tema dan makna puisi. Hasilnya disajikan dalam bentuk analisis deskriptif. Selain itu, hasil yang diperoleh melalui analisis juga dijustifikasi dengan hasil wawancara dengan guru untuk melihat relevansi hasil kajian dengan pembelajaran di SMA.

\section{HASIL DAN PEMBAHASAN}

\section{Literasi Antikorupsi dalam Puisi A. Mustofa Bisri}

A. Mustofa Bisri atau biasa disapa Gus Mus adalah penyair dengan latar belakang keislaman yang kuat. Puisi-puisi yang ditulisnya pun tidak jauh dari napas religiusitas. Puisi kritik yang ditulis tidak dapat dijauhkan dari tema keagamaan. Nilainilai keagamaan inilah yang dijadikan pelajaran untuk menyerap dan menanamkan nilai antikorupsi. Hal ini terdapat pada antologi Aku Manusia. Ada 47 puisi yang terhimpun dalam kumpulan puisi ini. Dari puisi-puisi tersebut, ditemukan pelajaran atau amanat yang dapat dijadikan bahan untuk memperkaya literasi antikorupsi. Literasi antikorupsi yang dimaksud antara lain literasi tentang kejujuran, menjadi diri 
sendiri, tanggung jawab, ketidakadilan, tafakkur, keikhlasan, kesederhanaan, kekayaan, dan pengendalian diri. Pelajaran-pelajaran tersebut akan sangat berharga bagi pembentukan nilai antikorupsi para pembaca.

\section{Nilai Kejujuran}

Pelajaran pertama yang dapat diambil dari puisi A. Mustofa Bisri adalah pelajaran tentang kejujuran atau literasi kejujuran, khususnya kejujuran terhadap diri sendiri. Pelajaran ini ditemukan pada puisi "Misteri" yang ditulis pada tahun 2002. Alih-alih berbicara tentang kejujuran, puisi "Misteri" berisi tentang ketidakjujuran. Berikut penggalan kutipannya.

Bagaimana kau menyembunyikan cinta

Sedangkan kedua matamu cermin terbuka

Dan mulutmu tak berhenti mereka-reka kata

Agar isi dada tetap terjaga?

Apakah seperti seharusnya atau hanya menipu diri

Atau takut tak dihargai

Maka kau rahasiakan dirimu setiap hari

Seperti pencuri?

(Bisri, 2015, hlm. 103)

Penggalan puisi di atas berkisah tentang seseorang yang menyembunyikan banyak rahasia di dalam dirinya. Ia digambarkan bersembunyi di balik gaya bicara, tutur kata, dan penampilan fisik untuk menutupi fakta yang sebenarnya. Entah, puisi ini ditujukan kepada siapa. Akan tetapi, dalam konteks politik, penggalan puisi tersebut bisa ditujukan pada sosok politisi yang suka bermain muka untuk menaikkan citra. Baris atau takut tak dihargai memberikan penguatan bahwa citra dirilah yang menjadi tujuan utama seorang politisi berlaku tidak jujur, bahkan terhadap dirinya sendiri.

Sindiran Gus Mus tersebut memberikan pelajaran tentang pentingnya menanamkan nilai kejujuran dalam diri. Dalam kaitannya dengan masalah korupsi, kejujuran merupakan nilai dasar yang wajib ditanamkan kepada setiap orang. Tindakan korupsi pasti melibatkan tindakan ketidakjujuran. Dalam puisi tersebut, nyata dikatakan Maka kau rahasiakan dirimu setiap hari seperti pencuri?.

\section{Nilai Kemandirian}

Ketidakjujuran pada diri sendiri seperti yang ditemukan pada puisi "Misteri" di atas dipertegas lagi pada puisi "Orang-Orang Negeriku". Puisi "Orang-Orang Negeriku" menggambarkan perilaku kebanyakan orang Indonesia yang selalu bersembunyi di balik pakaian yang dikenakannya, seperti tergambar pada penggalan berikut.

$$
\begin{gathered}
\text { orang-orang negeriku } \\
\text { tak boleh pakai baju } \\
\text { orang-orang negeriku } \\
\text { bila pakai baju } \\
\text { diri mereka tertelan baju }
\end{gathered}
$$

(Bisri, 2015, hlm.33)

Apabila mengenakan baju militer, orang tersebut akan otomatis menjadi otoriter. Apabila mengenakan baju Eropa, mereka menjadi lupa dengan saudaranya. Tidak ada kepribadian yang kuat dalam perilaku orang-orang Indonesia. Tidak ada nilai dasar yang digunakan sebagai pegangan dalam menjalankan peran yang diberikan oleh 
Tuhan. Orang Indonesia terkungkung di dalam sistem yang dibuat sendiri sehingga tidak ada kemerdekaan untuk menjadi diri sendiri.

Pola hidup tanpa prinsip inilah yang membuka peluang lahirnya perilaku korup pada sebagian besar orang Indonesia. Orang yang tidak mampu menjadi dirinya sendiri memiliki kecenderungan mudah tergoda dengan apa yang dimiliki oleh orang lain. Bahkan, orang rela melakukan apa pun hanya untuk bisa memiliki apa yang dimiliki orang lain, termasuk dengan mencuri atau korupsi.

\section{Nilai Tanggung Jawab}

Tanggung jawab terhadap tugas dan pekerjaan akan menjauhkan seseorang dari perilaku korup. Tanggung jawab adalah keadaan wajib menanggung segala sesuatunya. Maksudnya, kalau terjadi apa-apa boleh dituntut, dipersalahkan, diperkarakan, dan sebagainya. Seseorang yang di dalam dirinya sudah tertanam rasa tanggung jawab, pasti akan takut melakukan perbuatan yang salah atau melanggar hukum, termasuk di dalamnya korupsi.

Pelajaran tentang tanggung jawab ditemukan pada puisi "Tahakkumi". Dalam bahasa Indonesia, kata tahakkumi dapat diartikan sebagai "hukumlah aku/kami”". Hukumlah atas kebodohan, ketamakan, dan keberanian kami dalam mempermainkan tanggung jawab yang dibebankan kepada kami.

\section{TAHAKKUMI}

mengapa ketika sekalian alam
tak sanggup menerima
tugas mengelola bumi
kalian mengajukan diri
tak tahu diri
kini
ketika dengan jumawa
kalian melibas dan merusak
saling tumpas dan saling gasak
lalu
langit sekalian badai dan petirnya
laut sekalian kerak dan ombaknya
bumi sekalian tanah dan sampahnya
dunia sekalian harta dan bendanya
membantu kalian
mempercepat kehancuran,
makhluk angkuh,
kalian mengeluh
atau lupa?

(Bisri, 2015, hlm. 54)

Puisi di atas membahas perilaku tidak bertanggung jawab para pemimpin negeri. Dengan berani, mereka mengajukan diri untuk menjadi khalifatullah fir ardh, dengan tugas utama mengelola bumi. Namun, justru mereka memainkan tanggung jawab tersebut untuk kepentingan mereka sendiri yang berakibat pada timbulnya kehancuran.

\section{Nilai Keadilan}

Prinsip utama yang harus dijalankan para pemimpin bangsa ini adalah menghadirkan keadilan sosial bagi seluruh rakyat Indonesia. Keadilan ini tidak akan 
pernah terwujud selama pemimpinnya hanya mengurusi kepentingan diri dan golongannya. Menjalankan sistem pemerintahan yang tidak adil justru akan menjadikan jurang kesenjangan sosial semakin lebar, sebagaimana tampak pada penggalan puisi "Banyak yang Tinggal" berikut.

Banyak yang tinggal di gedung beratap beton

Menimbun rongsokan berton-ton

Banyak yang tinggal di emper-emper sempit dipeluk langit

Menjumputi remah-remah hidup yang pahit

(Bisri, 2015, hlm. 39)

Puisi di atas merupakan kritik atas kegagalan pemerintah menjalankan prinsip keadilan sosial. Diksi menimbun rongsokan berton-ton ini merupakan cerminan perilaku sebagian masyarakat Indonesia yang hidup dalam kemewahan dan kegelimangan harta. Hal inilah pemicu lahirnya korupsi.

Apabila direnungkan secara dalam, kurang apa hidup para pemimpin bangsa ini sehingga mereka masih bisa korupsi jika bukan untuk memenuhi gaya hidup yang dalam terminologi puisi di atas digambarkan sebagai rongsokan. Padahal, di samping mereka ada sekelompok orang yang bahkan hanya tinggal di emper-emper toko.

Hal ini memberikan pelajaran besar untuk memiliki rasa kepedulian sosial. Kepedulian dan kepekaan sosial yang besar akan menjadi modal kuat seseorang menjalankan nilai-nilai keadilan, terutama ketika berada pada posisi pengambil kebijakan. Sistem korup yang dijalankan pemerintah telah menimbulkan kerusakan yang teramat parah bagi bangsa. Hal ini tidak menjadi kesadaran bersama sehingga kemudian dijadikan alasan untuk mengubah perilaku dan tatanan nilai yang dianut. Jika sudah demikian, hanya tinggal bersiap-siap untuk menerima balasan dari Tuhan.

Tafakkur menjadi pelajaran penting yang harus senantiasa ditanamkan dalam diri. Kerusakan yang sudah ditimbulkan oleh keangkuhan, keserakahan, kebodohan, dan ketamakan harus menjadi bahan renungan untuk memperbaiki diri. Karena jika hal itu tidak dilakukan, tidak butuh waktu lama bagi Tuhan untuk menunjukkan kekuasaannya.

Lihatlah

Inilah pesan Mustofa Bisri dalam puisi "Berapa Lama".

Untuk memporak-porandakan Bumi Iskandar Muda

Bumi Mangkunegara dan Hamengkubuwana

Untuk melenyapkan bangunan-bangunan dan isinya

Tuhan kalian tak memerlukan

Hitungan tahun, bulan, jam, atau menit

Tak memerlukan masa

Tinggal mengarahkan alam

Dan kebodohan manusia penghuninya

(Bisri, 2015, hlm. 65)

Kesadaran bahwa Tuhan tidak membutuhkan waktu lama, tidak memerlukan bantuan siapa-siapa untuk memporak-porandakan bumi beserta isinya patut menjadi bahan untuk ber-tafakkur. Jadi, untuk apa sebenarnya mengejar kekuasaan, menumpuk kekayaan, dan menghalalkan segala cara untuk mewujudkan keinginan jika Tuhan tidak rida dengan semua usaha untuk mencapai hal tersebut. Semua itu hanya akan berujung pada kerusakan dan kehancuran. Tinggal menunggu waktu saja.

Tafakkur ini akan menjadi pelajaran berharga untuk senantiasa memiliki kesadaran tentang keterbatasan sebagai manusia. Manusia tidak mungkin bisa berbuat sekehendak hatinya. Tidak mungkin semua keinginan manusia bisa diwujudkan jika tidak atas rida- 
Nya. Maka, menghalalkan segala cara untuk mewujudkan keinginan, termasuk di dalamnya korupsi, bisa diredam atau disebut dengan ber-tafakkur.

\section{Nilai Keikhlasan}

Nafsu berkuasa dan menumpuk-numpuk harta merupakan penyebab utama timbulnya masalah korupsi. Tidak ada lagi kata ikhlas dalam diri pelaku korupsi. Semua yang dilakukan dan dikorbankan merupakan upaya untuk mendapatkan imbal balik yang lebih besar. Maka, keikhlasan menjadi barang langka dalam kamus hidup koruptor.

Persoalan ini menjadi titik fokus dalam puisi "Kurban". A. Mustofa Bisri mengkritik politik kepentingan tersebut dalam terminologi ibadah kurban.

Mereka serahkan leher-leher mereka

Tapi Ibrahim tegas berkata

Kalian bukan Ismailku yang

Mengikhlaskan nyawanya

Demi Tuhannya

Kalian hanya daging

Dan darah kambing

Yang paling tinggi senilai kepentingan

kalian

Aku tak tahu apa firman Tuhan

(Bisri, 2015, hlm. 76)

Kurban dalam pandangan orang-orang yang gila kekuasaan dan kekayaan hanya senilai dengan kepentingan. Tidak ada muatan ukhrawi dalam ibadah kurban tersebut. Semua dilakukan hanya agar kepentingannya berjalan sebagaimana yang diharapkan. Ikhlas dalam beribadah, membantu sesama, atau mengabdi demi bangsa dan negara menjadi barang langka. Padahal, ikhlas menjalani kehidupan dengan aneka ragam cobaan dan ujian akan mampu mengantarkan seseorang menjadi pribadi mulia. Kerja ikhlas tanpa berharap pamrih dan imbalan akan mengantarkan seseorang terbebas dari berbagai konflik kepentingan, termasuk di dalamnya kepentingan untuk mengedepankan hak sebagian orang atau golongan.

\section{Nilai Kesederhanaan}

Prinsip hidup sederhana merupakan salah satu cara untuk menghindarkan diri dari tindak pidana korupsi. Kesederhanaan ini dapat diteladani pada diri Nabi Muhammad Saw. Sebagaimana dilukiskan dalam penggalan puisi "Bagaimana Aku Menirumu, O Kekasih" berikut.

$$
\begin{gathered}
\text { Engkau kaya dari dalam } \\
\text { Aku miskin luar-dalam } \\
\text { Miskin bagimu adalah pilihan } \\
\text { Miskin bagiku adalah keterpaksaan }
\end{gathered}
$$

(Bisri, 2015, hlm. 71)

Muhammad Saw. adalah uswatun khasanah (suri tauladan yang baik). Karakter dan akhlak mulia melekat dalam dirinya sehingga patut diteladani oleh umat-umatnya. Salah satu akhlak mulia tersebut adalah prinsip hidup sederhana yang beliau terapkan. Di dalam puisi tersebut dinyatakan miskin bagimu adalah pilihan. Artinya, Muhammad Saw merupakan seorang yang kaya, tetapi memilih hidup sederhana, tinggal di rumah kecil, makan seadanya, pakaian hanya dua-tiga potong, dan sebagainya. Padahal, di balik semua itu, beliau adalah sosok pedagang sukses yang kaya. Kesederhanaan hidup 
Muhammad Saw merupakan teladan luhur untuk terhindar dari keserakahan dan ketamakan. Dua hal yang menjadi pemicu tumbuhnya hasrat korupsi dalam diri manusia.

Selain berpedoman pada kesederhanaan, mengubah pandangan tentang definisi kekayaan atau kesuksesan juga pelajaran antikorupsi perlu ditanamkan. Dalam puisi A. Mustofa Bisri, nilai tersebut tampak pada puisi "Tentang Dua Orang Kaya dan Miskin”. Puisi tersebut mengisahkan perubahan nasib yang dialami oleh dua orang yang berbeda. Pertama, seseorang yang tadinya kaya dan banyak orang mendekatinya, tiba-tiba berubah menjadi miskin dan orang-orang pun menjauhinya. Dalam kesendiriannya, orang pertama tersebut justru menemukan Tuhan dan mendapatkan kedamaian hidup yang belum pernah dirasakan sebelumnya.

hingga akhirnya terlupakan sama sekali
lalu kesendiriannya menggiring dirinya kepadaNya yang
selama ini ia
abaikan
dan kini satu-satunya yang memberikan kedamaian
yang tak pernah ia rasakan sebelumnya
ia pun bersyukur sesyukur-syukurnya karena merasa paling
kaya di dunia

(Bisri, 2015, hlm. 92)

Orang kedua dikisahkan sebelumnya miskin dan dijauhi oleh orang lain, tiba-tiba menjadi seseorang yang kaya raya sehingga orang-orang yang sebelumnya menjauhinya pun berbalik arah mendatanginya. Orang kedua ini pun lupa kepada Tuhan yang selama ini dimintai permohonan doa dan kekuatan. Hal yang dapat dipetik dari kisah dua orang tersebut adalah kalimat kedamaian yang tak pernah ia rasakan sebelumnya, ia pun bersyukur sesyukur-syukurnya karena merasa paling kaya di dunia. Orang ini merasa kaya justru ketika mendapati dirinya dalam keadaan tidak memiliki harta. Hal yang dimiliki hanya kedamaian hidup karena merasa dekat dengan Tuhan. Hal ini dapat menjadikan perasaan sebagai manusia paling kaya di dunia.

Dari sinilah dapat diambil kesimpulan bahwa kekayaan yang sejati hanyalah ketika bersama Tuhan. Ada kedamaian hidup yang menjadikan semua persoalan menjadi lebih ringan dihadapi. Jadi, kekayaan di sini bukan pada kekayaan materi, melainkan kekayaan hati. Orang yang hanya mengejar kekayaan materi, tidak akan pernah mendapatkan kedamaian hati. Hidupnya miskin, meskipun bergelimang harta. Sebaliknya, orang yang senantiasa menghadirkan Tuhan di dalam hatinya, akan merasa memiliki segalanya meskipun hidup dalam keadaan yang seadanya. Pelajaran inilah yang perlu dipetik dan ditanamkan dalam diri agar senantiasa terhindar dari nafsu duniawi, termasuk di dalamnya korupsi.

\section{Nilai Pengendalian Diri}

Puncak dari nilai pendidikan antikorupsi yang dapat diambil dari puisi A. Mustofa Bisri adalah nilai tentang pengendalian diri. Pelajaran ini ditemukan dalam puisi "Kepada Anakku". Puisi ini bercerita tentang pesan seorang ayah kepada anaknya. Inti makna dari puisi ini adalah pesan agar si anak menjadi manusia yang merdeka tanpa melanggar batas-batas kemerdekaan yang lainnya karena merdeka bukan berarti boleh berbuat sekehendak hati seperti pada Karena kau tak hidup sendiri, begitu menabrak kemerdekaan pihak lain, kemerdekaanmu harus berhenti.

Dengan demikian, pengendalian diri menjadi kunci dalam proses memperoleh kemerdekaan yang hakiki. Pengendalian diri di sini juga termasuk kemampuan 
menundukkan keinginan dan nafsu yang ada dalam diri sendiri, sebagaimana tampak pada penggalan puisi berikut.

Ingatlah anakku, Kau tak akan pernah benar-benar merdeka

Sebelum kau mampu melepaskan diri

Dari belenggu perbudakan oleh selain Tuhanmu

Termasuk penjajahan nafsumu sendiri

(Bisri, 2015, hlm. 82)

Korupsi selalu timbul dari ketidakmampuan manusia mengendalikan hawa nafsunya. Oleh karena itu, puisi tersebut memiliki pesan penting dalam upaya memberikan kesadaran tentang pentingnya mengendalikan hawa nafsu, termasuk nafsu berkuasa dan menumpuk harta atau nafsu duniawi. Dalam konsep Fawaid, mentalitas atau nafsu serba dunia inilah yang menyebabkan begitu masifnya tindakan korupsi (Fawaid, 2010).

Demikianlah nilai antikorupsi yang dapat dipetik dari puisi A. Mustofa Bisri. Nilai-nilai tersebut merupakan bahan kajian penting dalam upaya mengembangkan literasi antikorupsi, khususnya bagi generasi muda dan siswa SMA. Selanjutnya, nilainilai antikorupsi tersebut dilihat relevansinya dengan materi pembelajaran puisi di SMA.

\section{Relevansi Puisi A. Mustofa Bisri dalam Pembelajaran Puisi di SMA}

Nilai-nilai pendidikan antikorupsi sebagaimana sudah dikemukakan di depan sangat relevan untuk dijadikan sebagai materi pembelajaran sastra di SMA. Dalam struktur kurikulum 2013 edisi revisi, materi puisi disajikan pada kelas X dengan kompetensi dasar sebagai berikut. (3.16) Mengidentifikasi suasana, tema, dan makna beberapa puisi yang terkandung dalam antologi puisi yang diperdengarkan atau dibaca; (3.17) Menganalisis unsur pembangun puisi; (4.16) Mendemonstrasikan (membacakan atau memusikalisasikan) satu puisi dari antologi puisi atau kumpulan puisi dengan memerhatikan vokal, ekspresi, dan intonasi (tekanan dinamik dan tekanan tempo); (4.17) Menulis puisi dengan memperhatikan unsur pembangunnya, meliputi: tema, diksi, gaya bahasa, imaji, struktur, dan perwajahan.

Puisi-puisi A. Mustofa Bisri di atas dapat digunakan sebagai materi ajar yang akan memperkaya nilai antikorupsi siswa. Sejauh ini, berdasarkan informasi yang dihimpun dari guru, belum ada upaya internalisasi nilai-nilai antikorupsi dalam pembelajaran puisi. Dengan hadirnya kajian ini, paling tidak akan memperkaya wawasan guru dalam mengembangkan materi pembelajaran puisi dengan menitikberatkan pada nilai antikorupsi.

Berdasarkan hasil wawancara dengan guru-guru bahasa Indonesia SMA, diperoleh informasi bahwa selama ini, upaya mengaitkan materi puisi dengan nilai antikorupsi dilakukan dengan memilih puisi-puisi yang membahas masalah korupsi, misalnya puisi "Sajak Sebatang Lisong" karya W. S. Rendra. Secara substansi, puisi tersebut memang menyoroti persoalan korupsi pemerintahan Orde Baru. Kajian ini akan memberikan dimensi lain bahwa penanaman nilai antikorupsi tidak hanya dari pemilihan puisi bertema korupsi, tetapi bisa juga dengan menekankan pada puisi-puisi yang berlandaskan pada nilai-nilai luhur kemanusiaan dan keagamaan. Kemudian, nilai-nilai luhur tersebut ditarik kepada persoalan korupsi.

Pada Kompetensi Dasar 4.17 tentang menulis puisi, upaya internalisasi nilai pendidikan antikorupsi dapat dilakukan dengan mengikuti langkah-langkah sebagai berikut. (1) Peserta didik mengamati kasus-kasus korupsi dari berbagai media; (2) 
Peserta didik mengidentifikasi, menalar, dan mengasosiasikan kasus-kasus korupsi ke dalam tema-tema tertentu; (3) Peserta didik mencoba menulis puisi antikorupsi mulai dari yang sederhana; (4) Peserta didik mengomunikasikan karya kepada temannya lalu hasilnya dipublikasikan dalam bentuk majalah dinding atau mading serta buku kumpulan puisi (Ulya dan Wardani, 2017).

Upaya menggunakan puisi-puisi antikorupsi dalam pembelajaran apresiasi puisi merupakan langkah konkret menginternalisasi nilai-nilai pendidikan antikorupsi. Internalisasi nilai pendidikan antikorupsi ini sejalan dengan konsep yang ditawarkan oleh KPK dalam upaya penanggulangan korupsi yang dilakukan melalui empat pendekatan, yakni pendekatan hukum, pendekatan bisnis, pendekatan pasar atau ekonomi, dan pendekatan budaya (Wijayanto dalam Sofia, 2011).

Pendidikan dipandang memiliki peran strategis dalam membangun kembali pemahaman yang benar dari masyarakat mengenai korupsi, meningkatkan kesadaran (awareness) terhadap segala potensi tindak koruptif yang terjadi, tidak melakukan tindak korupsi sekecil apapun, dan berani menentang tindak korupsi yang terjadi (Sofia, 2011). Upaya internalisasi pelajaran antikorupsi ini akan mendukung upaya implementasi pendidikan antikorupsi. Pendidikan antikorupsi menekankan pada pembangunan karakter antikorupsi (anti-corruption character building) pada diri individu siswa (Sofia, 2011). Tujuan utamanya adalah peserta didik mampu memahami dan menerapkan nilai-nilai antikorupsi dalam kehidupan sehari-hari.

Pentingnya menitipkan upaya pencegahan perilaku korup pada peserta didik karena generasi muda merupakan kelompok usia terbesar penduduk di sejumlah negara (Wickberg, 2013). Hal ini memberikan penguatan bahwa generasi muda haruslah dilibatkan dalam upaya-upaya perubahan masalah sosial, tak terkecuali upaya pemberantasan korupsi. Oleh karena itu, pendidikan antikorupsi memiliki posisi strategis di dalam upaya pencegahan tindak pidana korupsi.

Upaya pencegahan korupsi dapat dimulai dengan menanamkan nilai-nilai antikorupsi pada semua individu. Ada 9 (sembilan) nilai antikorupsi yang dirumuskan oleh KPK, yaitu: kejujuran, kepedulian, kemandirian, kedisiplinan, tanggung jawab, kerja keras, sederhana, keberanian, dan keadilan (Bura \& Puspito, 2014). Nilai-nilai antikorupsi yang disampaikan oleh A. Mustofa Bisri di atas dapat ditransfer kepada peserta didik agar tumbuh sikap peduli terhadap masalah korupsi, lebih-lebih mampu membentuk generasi antikorupsi yang akan membawa perubahan pada bangsa Indonesia di masa mendatang. Dengan meneladani karakterkarakter luhur bangsa yang berlandaskan pada nilai-nilai keagamaan, diharapkan akan tumbuh benteng-benteng untuk memperkuat pertahanan mereka agar terhindar dari berbagai godaan korupsi.

\section{SIMPULAN}

Berdasarkan hasil dan pembahasan yang sudah dikemukakan di depan, dapat ditarik simpulan bahwa terdapat tujuh nilai pendidikan antikorupsi yang dapat dipetik dari puisi A. Mustofa Bisri, yaitu kejujuran, kemandirian, tanggung jawab, keadilan, keikhlasan, kesederhanaan, dan pengendalian diri. Nilai pendidikan antikorupsi tersebut dapat diinternalisasi ke dalam kegiatan pembelajaran di tingkat SMA dengan menggunakannya sebagai materi ajar dalam pembelajaran apresiasi puisi. Dari proses inilah diharapkan akan tumbuh kesadaran dalam diri peserta didik tentang pentingnya membentengi diri dari godaan korupsi. 


\section{DAFTAR PUSTAKA}

Alniezar, F. (2018). Tirto. Retrieved from Gus Mus: Kiai yang Penyair, Ulama yang Pemikir: https://tirto.id/gus-mus-kiai-yang-penyair-ulama-yangpemikir-cLix

Anedo, O. A. (2011). The Place of Poetry in Contemporary Chinese and Igbo Politics. African Journal of Political Science and International Relations, 5(6), 271-282.

Arisnawati, N. (2011). Gambaran Kemiskinan dalam Puisi K.H.A. Mustofa Bisri. Sawerigading , 17(1), 147-156.

Bisri, A. M. (2005). Pahlawan dan Tikus. Yogyakarta: Hikayat Publishing.

Bisri, A. M. (2016). Aku Manusia. Rembang: Mata Air Indonesia.

Bura, R. O., \& Puspito, N. T. (2014). Nilai dan Prinsip Anti Korupsi. In N. T. Puspito, Pendidikan Antikorupsi untuk Perguruan Tinggi (pp. 73-86). Jakarta: Kementerian Pendidikan dan Kebudayaan.

Fawaid, A. (2010). Islam, Budaya Korupsi, dan Good Governance. Karsa, XVII(1), 18-26.

Mahayana, M. S. (2016). Jalan Puisi: Dari Nusantara ke Negeri Poci. Jakarta: Kompas.

Mujiningsih, E. N. (2007). K.H. A. Mustofa Bisri: Penyair yang Menyikapi Keotoriteran Masa Orde Baru dan Kebebasan Masa Reformasi. Atavisme, 10(2), 11-25.

Nakti, E. K., Ghazali, A. S., \& Maryaeni, M. (2016). Wujud Pengakuan Adanya Norma-Norma Mutlak dari Tuhan dalam Kumpulan Cerpen Lukisan Kaligrafi Karya A. Mustofa Bisri. Jurnal Pendidikan: Teori, Penelitian, dan Pengembangan, 1(8), 1487-1499.

Perrine, L. (1974). Literature (Structure, Sound, and Sense). Atlanta: Harcourt Brave Jovanovich.

Shandy, T. M. (2016). Religious Values In Gus Jakfar's Short Story By Ahmad Mustofa Bisri. Journal of Education and Social Sciences, 3, 146-150.

Sofia, A. I. (2011). Model Pembelajaran Mata Kuliah Anti-Korupsi. In Pendidikan Anti-Korupsi untuk Perguruan Tinggi (pp. 3-20). Jakarta: Kementerian Pendidikan dan Kebudayaan RI.

Srestha, A. P. (2000). Protest Poetry: The Voice of Conciences. CNAS Journal, 27(2), 34-45.

Suharto, A. W. (2008). Kepenyairan A. Mustofa Bisri Berangkat dari Ajaran Alqur'an dan Alhadis. Insania, 13(1), 130-150.

Sutopo, H. B. (2006). Metode Penelitian Kualitatif. Surakarta: UNS Press.

Tjahjono, T. (2012). Melawan Kekuasaan dengan Puisi. Atavisme, 15(1), 49-58.

Ulya, C., Wardani, N. E., \& Mujiyanto, Y. (2016). Metafora dalam Puisi Antikorupsi Karya Penyair Indonesia. Atavisme, 19(2), 206-219.

Ulya, C., Wardani, N. E., \& Mujiyanto, Y. (2016). Muatan Pendidikan Antikorupsi dalam Mata Kuliah Pengkajian dan Apresiasi Puisi di Jawa Tengah dan Yogyakarta. Journal Indonesian Language Education and Literature, 2(1), 60-75.

Ulya, C. \& Wardani, N. E. (2017). Internalisasi Nilai Pendidikan Antikorupsi dalam Mata Kuliah Kajian dan Apresiasi Puisi. Konferensi Nasional Bahasa dan Sastra IV (pp. 121-125). Surakarta: Program Doktor Pendidikan Bahasa Indonesia FKIP UNS. 


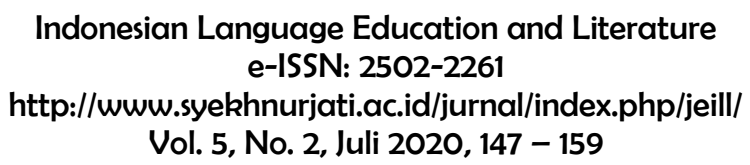

Wahyuni, L. (2016). Pembentukan Citra Diri dalam Puisi "Kau Ini Bagaimana atau Aku Harus Bagaimana" Karya K.H. A. Mustofa Bisri. Kembara: Jurnal Keilmuan Bahasa, Sastra, dan Pengajarannya, 2(2), 187-194.

Wickberg, S. (2013). Best Practices in Engaging Youth in the Fight Against Corruption. London: Transparency International.

Wijaya, D. W. (2018). Tafsir Hermeneutik Puisi Sufi A. Mustofa Bisri. Seminar Nasional Kajian Bahasa, Sastra, dan Pengajarannya V (pp. 327-332). Surakarta: Universitas Muhammadiyah Surakarta. 